\title{
PENGEMBANGAN YOGHURT JAGUNG BERBASIS JAGUNG PIPILAN PULUT PUTIH, PULUT UNGU DAN PROVIT A
}

\author{
[Development of Corn Yoghurt Based on Pulut Putih, Pulut Ungu and Provit A Corn Flakes] \\ Mutia Devi Ariyana (1) ${ }^{(1)}$ Moegiratul Amaro(1), Baiq Rien Handayani ${ }^{1}$, Nazaruddin ${ }^{1}$, Sri \\ Widyastuti $^{1}$ \\ 1)Program Studi Ilmu dan Teknologi Pangan \\ Fakultas Teknologi Pangan dan Agroindustri Universitas Mataram \\ *email: mutiadevi0705@gmail.com
}

Diterima 18 April 2021 / Disetujui 1 Mei 2021

\begin{abstract}
The aim of this study was to find out the characteristics of corn yogurt from several varieties of corn. This study was an experimental study using a Complete Randomized Design consisting of 1 factor, that was the type of corn variety (white pulut, purple pulut and provit A). The results showed that type of corn variety gave a real different effect on the $\mathrm{pH}$, total lactic acid bacteria, taste, aroma and appearance of yogurt. Purple Pulut variety was the best treatment based on $\mathrm{pH}$ value of 3.88, the highest total Lactic Acid Bacteria was $8.7 \mathrm{CFU} / \mathrm{ml}$ logs, appearance that meets sni requirements that were viscous, taste and aroma that can be accepted by panelists.
\end{abstract}

Keywords: Corn, provit A, white pulut, purple pulut, yogurt

\begin{abstract}
ABSTRAK
Tujuan dari penelitian ini adalah untuk mengetahui karakteristik kimia, mikrobiologis dan sensoris yoghurt jagung dari beberapa varietas jagung. Penelitian ini adalah penelitian eksperimental menggunakan Rancangan Acak Lengkap yang terdiri dari 1 faktor yaitu jenis varietas jagung (pulut putih, pulut ungu dan provit A). Hasil penelitian menunjukkan bahwa jenis varietas jagung memberikan pengaruh yang berbeda nyata terhadap $\mathrm{pH}$, total bakteri asam laktat, rasa, aroma dan kenampakan yogurt. Penggunaan varietas Jagung Pulut Ungu merupakan perlakuan terbaik berdasarkan nilai $\mathrm{pH} 3,88$, total Bakteri Asam Laktat tertinggi yaitu 8,7 log CFU/ml, kenampakan yang memenuhi persyaratan SNI yaitu kental serta rasa dan aroma yang dapat diterima oleh panelis.
\end{abstract}

Kata kunci: Jagung, provit $A$, pulut putih, pulut ungu, yogurt

\section{PENDAHULUAN}

Pandemi Covid-19 menggiring tatanan masyarakat menuju era new normal yang ditandai dengan pergeseran pola konsumsi ke arah makanan dan minuman yang mampu meningkatkan sistem imun tubuh atau dikenal dengan pangan fungsional. Salah satu jenis pangan fungsional yang banyak dikenal dan dikonsumsi masyarakat adalah produk fermentasi termasuk yoghurt. Yoghurt dapat memperbaiki kondisi mikroflora di usus dan berdampak positif terhadap imunitas tubuh (Djunaedi, 2007; Kusumaningsih, 2014).
Aspek fungsional yoghurt salah satunya dapat ditingkatkan dengan variasi bahan yang digunakan. Data Dinas Peternakan dan Kesehatan Hewan dalam Statistik Sektoral Bidang Ekonomi tahun 2019 yang diterbitkan oleh Dinas Komunikasi Informatika dan Statistik Nusa Tenggara Barat (NTB), menunjukkan populasi sapi di NTB didominasi oleh sapi potong yang menyebabkan keterbatasan produksi dan tingginya harga jual susu sapi. Keterbatasan susu sapi sebagai bahan baku pembuatan yoghurt juga diperkuat dengan ketidaksesuaian beberapa konsumen baik dari segi sensoris maupun adanya potensi alergi dari penggunaan 
Versi Online:

http://www.profood.unram.ac.id/index.php/profood e-ISSN: 2443-3446

susu sapi. Kondisi ini mendorong pemanfaatan bahan baku nabati sehingga dapat mengurangi kebutuhan susu hewani dalam pembuatan yoghurt.

Beberapa bahan nabati telah dikaji sebagai bahan baku dalam pembuatan yoghurt diantaranya adalah jagung manis (Laeli, 2016), kedelai (Ningsih, 2018), kacang komak (Usmaningtia 2019; Nurkayanti 2019) dan santan (Hartini, 2020; Meilawanti, 2020). Berdasarkan parameter sensoris, yoghurt berbahan baku kedelai dan kacang komak umumnya memiliki aroma langu (Ningsih, 2018; Usmaningtia 2019; Nurkayanti 2019) dan yoghurt berbahan baku santan memiliki aroma tengik (Hartini, 2020; Meilawanti, 2020) yang kurang disukai panelis, sedangkan yoghurt berbahan baku jagung umunya memiliki aroma khas jagung yang disukai panelis (Laeli, 2016). Oleh karena itu, Jagung memiliki potensi besar untuk dikembangkan sebagai bahan baku pembuatan yoghurt karena secara sensoris lebih disukai karena tidak beraroma langu, jagung juga memiliki kandungan nutrisi dan serat tinggi, serta mengandung prebiotik berupa fruktooligosakarida (FOS) yang dapat meningkatkan jumlah dan aktivitas dari probiotik pada yoghurt (Muchtadi, 2006).

Potensi sumber daya jagung NTB juga sangat mendukung pengembangan komoditas palawija ini menjadi bahan baku minuman pada skala industri karena menurut data BPS Provinsi NTB (2019) produksi jagung NTB mencapai 2.084.929 ton sehingga Provinsi NTB merupakan salah satu sentra produksi jagung yang berada pada urutan ke-5 nasional (Kementerian Pertanian Republik Indonesia, 2018). Selain jagung manis yang sudah umum dimanfaatkan oleh masyarakat, menurut Balai Pengkajian Teknologi Pertanian (BPTP) NTB (2020) saat ini terdapat beberapa Varietas Unggul Baru (VUB) yang belum diketahui dan dimanfaatkan oleh masyarakat diantaranya adalah Jagung Pulut Putih dan Ungu serta Jagung Provit A. Berbeda dengan jagung manis yang umumnya dijual dalam keadaan segar, Jagung Pulut Putih maupun Ungu dan Jagung Provit A umumnya dijual sebagai jagung pipilan.
Pro Food (Jurnal IImu dan Teknologi Pangan) Vol 7 No. 1 Mei 2021 ISSN: 2443-1095

Ketersediaan varietas jagung jenis baru yang belum dimanfaatkan secara optimal ini membuka peluang bagi pengembangan varian yoghurt baru berbasis jagung pipilan Pulut Putih, Pulut Ungu dan Provit A. Melalui penelitian ini diharapkan dapat diketahui karakteristik kimia, mikrobiologis dan sensoris yoghurt jagung pipilan Pulut Putih, Pulut Ungu dan Provit A.

\section{Bahan}

\section{BAHAN DAN METODE}

Bahan yang digunakan diantaranya Jagung varietas Pulut Putih, Pulut Ungu dan Provit A dari BPTP NTB, air mineral (Narmada, Indonesia), susu skim, gula pasir, aquades, buffer fosfat, media De Man Rogosa and Sharpe Broth (MRSB) (Oxoid, Inggris), media De Man Rogosa and Sharpe Agar (MRSA) (Oxoid, Inggris) dan starter L. bulgaricus dan S. thermophilus yang diperoleh dari Laboratorium Mikrobiologi Pangan, Fakultas Teknologi Pangan dan Agroindustri, Universitas Mataram.

\section{Pembuatan Kultur Murni}

Disiapkan kultur L. bulgaricus dan $S$. thermophilus yang diperoleh dari Laboratorium Mikrobiologi Pangan Fakultas Teknologi Pangan dan Agroindustri Universitas Mataram yaitu masing-masing sebanyak $1 \mathrm{ml}$, kemudian dilakukan penyegaran pada media deMan Rogosa and Sharp Broth (MRSB) 9 ml. Dilakukan inkubasi pada suhu $37^{\circ} \mathrm{C}$ selama 24 jam (Nizori dkk, 2008).

\section{Pembutan Kultur Siap Pakai}

Disiapkan sari jagung sebanyak dan dilakukan pasteurisasi pada suhu $90^{\circ} \mathrm{C}$ selama 15 menit. Setelah dipasteurisasi, sari jagung didinginkan hingga mencapai suhu $37^{\circ} \mathrm{C}$. Kultur murni sebanyak $3 \%$ dimasukkan ke dalam sari jagung manis kemudian diinkubasi pada suhu $37^{\circ} \mathrm{C}$ selama 24 jam (Aurum, 2009).

\section{Pembuatan Sari Jagung}

Jagung pipilan varietas Pulut Putih, Pulut Ungu dan Provit A diperoleh dari BPTP NTB. Jagung 
Versi Online:

http://Www.profood.unram.ac.id/index.php/profood e-ISSN: $2443-3446$

pipilan kemudian disortasi, dicuci dan direndam selama 12 jam. Jagung hasil perendaman kemudian direbus selama 30 menit pada suhu $100^{\circ} \mathrm{C}$. Jagung yang telah matang kemudian ditimbang dan ditambahkan air dengan rasio jagung dan air 1:2. Campuran air dan jagung kemudian dihancurkan menggunakan blender hingga menjadi bubur jagung. Bubur jagung kemudian disaring dengan menggunakan kain saring untuk mendapatkan sari jagung (Laeli dkk, 2016).

\section{Pembuatan Yoghurt Jagung}

Sari jagung sebanyak ditambahkan dengan gula sebanyak $20 \%$, susu skim sebanyak $10 \%$ kemudian diaduk. Sari jagung yang telah homogen kemudian ditempatkan pada botol kaca dan dipasteurisasi menggunakan waterbath dengan suhu $90^{\circ} \mathrm{C}$ selama 15 menit. Pendinginan dilakukan dengan mendinginkan sari jagung yang telah dipasteurisasi hingga mencapai suhu $37^{\circ} \mathrm{C}$. Proses inokulasi dilakukan dengan menambahkan starter L. bulgaricus dan $S$. thermophilus sebanyak $3 \%$, yang dilanjutkan dengan inkubasi pada suhu $37^{\circ} \mathrm{C}$ selama 16 jam (Laeli dkk, 2016).

\section{Parameter Pengamatan}

Parameter yang diamati dalam penelitian ini yaitu parameter mikrobiologis yaitu uji total Bakteri Asam Laktat (BAL), parameter kimia meliputi uji pH dan parameter sensoris yaitu rasa, aroma dan kekentalan.

\section{HASIL DAN PEMBAHASAN}

\section{Derajat keasaman (pH)}

Fermentasi yogurt memiiki prinsip utama mengubah glukosa menjadi asam laktat dengan bantuan bakteri asam laktat. Nilai pH yogurt pada berbagai varietas jagung dapat diamati pada Gambar 1.

\section{Pro Food (Jurnal IImu dan Teknologi Pangan) Vol 7 No. 1 Mei 2021 \\ ISSN: 2443-1095}

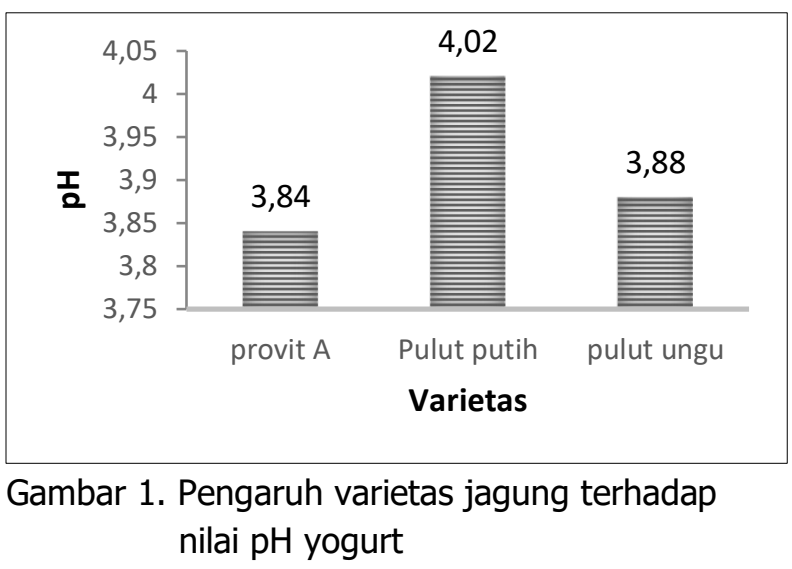

Berdasarkan hasil Analisa uji keragaman pada Gambar 1 menunjukkan bahwa varietas jagung memberikan pengaruh yang berbeda nyata terhadap nilai $\mathrm{pH}$ yogurt yang dihasilkan. Nilai $\mathrm{pH}$ tertinggi dihasilkan oleh varietas pulut putih dengan nilai $\mathrm{pH} 4,02$, sedangkan nilai $\mathrm{pH}$ terendah diperoleh varietas provit $\mathrm{A}$ dengan nilai $\mathrm{pH} 3,84$. Nilai $\mathrm{pH}$ varietas pulut ungu berada diantara pulut putih dan varietas provit $A$ dengan nilai 3,88 , tidak berbeda nyata dengan varietas provit $\mathrm{A}$ tetapi berbeda nyata dengan varietas pulut putih. Nilai pH yogurt dari masing-masing varietas sudah sesuai dengan Food Standards Australia New Zealand (2014) yaitu pH yogurt maksimal 4,5.

Pada saat proses fermentasi, bakteri asam laktat memproduksi asam sitrat, asam asetat serata asam laktat yang menyebabkan penurunan $\mathrm{pH}$ yogurt (Surono, 2004). Ion-ion $\mathrm{H}+$ yang terbentuk merupakan hasil disosiasi dari asam sehingga membentuk asam organik. Semakin banyak ion $\mathrm{H}+$ yang terbentuk berarti semakin banyak pula asam yang dihasilkan sehingga nilai pengukuran $\mathrm{pH}$ oleh elektroda $\mathrm{pH}$ meter semakin menurun.

Perbedaan $\mathrm{pH}$ yogurt yang dihasilkan dari berbagai varietas jagung disebabkan oleh perbedaan kandungan karbohidrat dari ketiga varietas jagung yang digunakan sebagai bahan baku. Berdasarkan penelitian pendahuluan yang dilakukan, kandungan karbohidrat varietas pulut putih sekitar $25 \%$, pulut ungu $26 \%$ dan provit $A$ sekitar 24\%. Karbohidrat dapat menstimulasi 
Versi Online:

http://Www.profood.unram.ac.id/index.php/profood e-ISSN: $2443-3446$

pertumbuhan BAL. semakin tinggi kandungan karbohidrat bahan maka semakin tinggi jumlah BAL sehingga semakin tinggi hasil metabolit terutama asam laktat yang terdisosiasi dalam ionion $\mathrm{H}$ sehingga $\mathrm{pH}$ menurun.

\section{Total BAL}

Berdasarkan SNI (2981: 2009), Yogurt adalah produk yang diperoleh dari fermentasi susu dan atau susu rekonstitusi dengan menggunakan bakteri Lactobacillus bulgaricus dan Streptococcus thermophillus dan atau bakteri asam laktat lain yang sesuai, dengan/atau tanpa penambahan bahan pangan lain dan bahan tambahan pangan yang diizinkan. Komposisi dan preparasi kultur starter sangat mempengaruhi kualitas yogurt yang dihasilkan. Selama pertumbuhan terjadi symbiosis antara bakteri asam laktat yang terkandung dalam yogurt (Lee dan Yucei, 2010).

Total bakteri asam laktat pada penelitian ini dapat diamati pada Gambar 2. Total Bal tertinggi diperoleh dari varitas jagung pulut ungu sebesar 8,07 log CFU/ml, dan jumlah BAL terendah diperoleh varietas pulut putih sebesar 7,66 log CFU/ml. total BAL varietas provit A sebesar 7,79 log CFU/ml, tidak berbeda nyata dengan varietas pulut putih tetapi berbeda nyata dengan varietas pulut ungu. Jumlah total BAL semua varietas memenuhi standar SNI yogurt yaitu sebesar $1,00 \times 10^{7} \mathrm{cfu} / \mathrm{ml}$.

Beberapa hal yang mempengaruhi pertumbuhan BAL antara lain lama fermentasi, lama inkubasi, $\mathrm{pH}$, media tumbuh, kandungan zat gizi substrat serta bahan yang digunakan (Nadra, 2007). Media tumbuh masing-masing perlakuan mempengaruhi jumlah BAL yogurt karena perbedaan kandungan karbohidrat masingmasing varietas. Varietas pulut putih memiliki kandungan karbohidrat sekitar 25\%, pulut ungu $26 \%$ dan provit A sekitar $24 \%$. Karbohidrat dapat menstimulasi pertumbuhan BAL.

Total BAL juga dipengaruhi oleh fase pertumbuhan BAL. pertumbuhan bakteri terbagi menjadi 4 fase yaitu fase lag, fase log, fase stasioner dan fase kematian. Pada fase log
Pro Food (Jurnal Ilmu dan Teknologi Pangan) Vol 7 No. 1 Mei 2021

ISSN: 2443-1095

jumlah sel mikroba mengalami kenaikan hingga mencapai masa akhir fase pertumbuhan mikroba. Laju pertumbuhan meningkat seiring dengan kandungan gizi yang terkandung dalam bahan (Ingraham dkk, 1983). Semakin tinggi kandungan karbohidrat bahan maka akan meningkatkan pertumbuhan sel mikroba pada fase log sehingga jumlah total BAL menjadi meningkat.

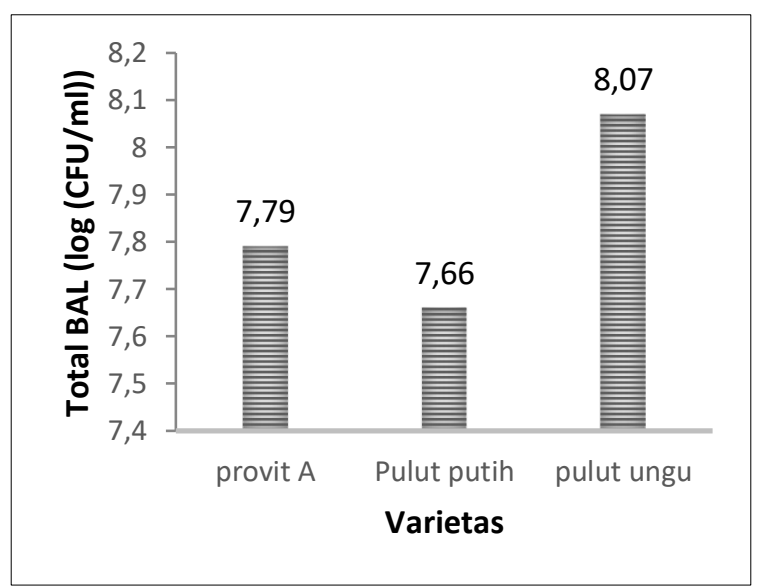

Gambar 2. Pengaruh varietas jagung terhadap total bakteri asam laktat pada yoghurt

\section{Rasa}

Standar mutu yoghurt berdasarkan Standar Nasional Indonesia (SNI) 2981:2009 mensyaratkan rasa yoghurt adalah asam atau memiliki rasa khas yoghurt (Badan Standarisasi Nasional, 2009). Pemecahan laktosa menjadi asam laktat oleh aktivitas Bakteri Asam Laktat akan meningkatkan keasaman susu, sehingga menyebabkan yoghurt memiliki rasa asam. Produksi asam laktat juga mestimulasi terjadinya koagulasi protein, sehingga produk yang terbentuk berupa susu yang mengalami menggumpal dengan cita rasa yang khas (Jannah dkk, 2014). Hubungan antara varietas jagung dengan rasa yoghurt jagung baik secara skoring maupun hedonik dapat dilihat pada Gambar 3. 
Versi Online:

http://Www.profood.unram.ac.id/index.php/profood e-ISSN: 2443-3446

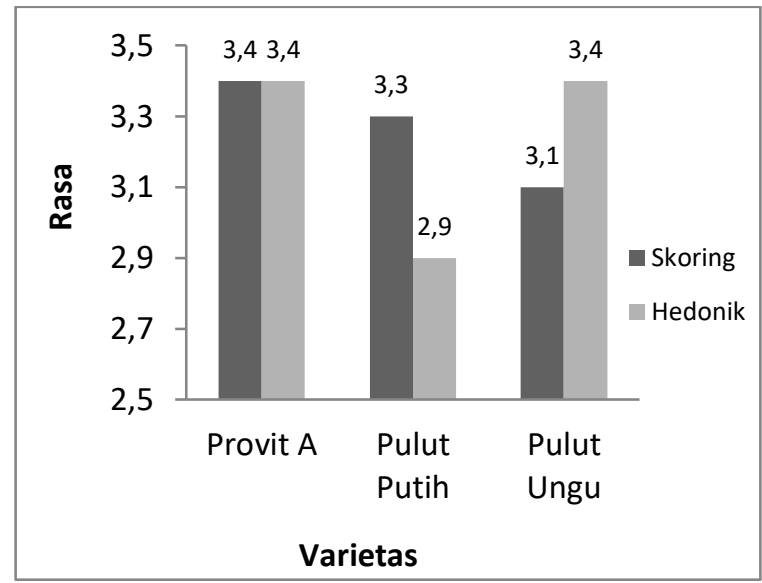

Gambar 3. Pengaruh varietas jagung terhadap rasa yoghurt

Gambar 3 menunjukkan bahwa varietas jagung tidak berpengaruh signifikan terhadap rasa yoghurt jagung. Rasa yoghurt jagung baik yang diuji secara skoring maupun hedonik menunjukkan tidak berbeda nyata antara varietas Pulut Putih, Pulut Ungu dan Provit A. Hasil uji sensoris secara skoring berada pada nilai 3,1-3,4 yang menunjukkan bahwa rasa yoghurt jagung dari seluruh varietas berada pada kriteria "agak asam". Hal ini menunjukkan seluruh perlakuan masih berada di bawah standar mutu yoghurt berdasarkan Standar Nasional Indonesia (SNI) 2981:2009 mensyaratkan rasa yoghurt adalah asam. Akan tetapi, jika ditinjau berdasarkan nilai $\mathrm{pH}$ yang berasosiasi dengan rasa asam pada yoghurt, maka seluruh perlakuan telah memenuhi persyaratan $\mathrm{pH}$ yoghurt berdasarkan Food Standards Australia New Zealand (2014) yaitu $\mathrm{pH}$ yogurt maksimal 4,5. Hasil uji sensoris secara hedonik, rasa yoghurt jagung dari seluruh varietas berada pada nilai 2,9-3,44 yang menunjukkan bahwa yoghurt jagung dari seluruh varietas berada pada kriteria "agak suka". Kondisi ini terkait erat dengan hasil uji sensoris secara skoring yang yang menunjukkan bahwa yoghurt dari seluruh varietas jagung yang digunakan belum mencapai kriteria "asam" sehingga tidak mencirikan karakteristik khas yoghurt.

\section{Aroma}

Pro Food (Jurnal Ilmu dan Teknologi Pangan) Vol 7 No. 1 Mei 2021

ISSN: 2443-1095

Standar mutu yoghurt berdasarkan Standar Nasional Indonesia (SNI) 2981:2009 mensyaratkan aroma yoghurt adalah normal atau memiliki aroma khas yoghurt (Badan Standarisasi Nasional, 2009). Aroma atau flavor khas yoghurt terbentuk oleh komponen asam laktat, sisa-sisa aldehida, diasetil, asam asetat dan komponen volatil lainnya (Tamime dan Robinson, 2007). Hubungan antara varietas jagung dengan aroma yoghurt jagung baik secara skoring maupun hedonik dapat dilihat pada Gambar 4.

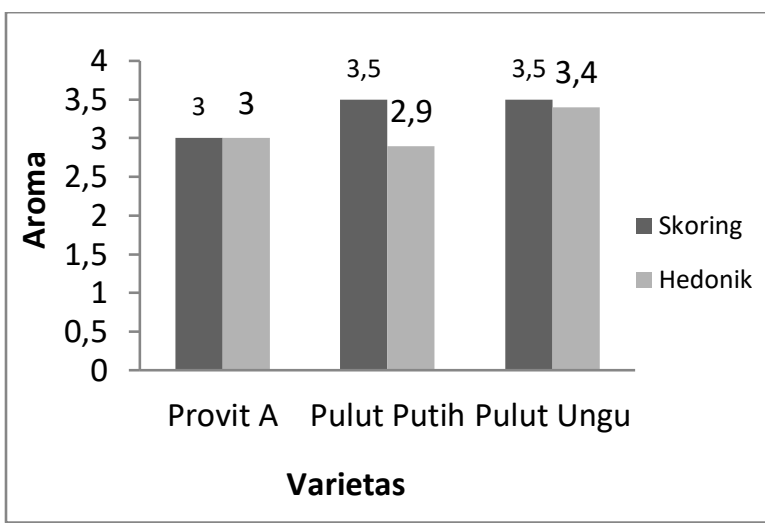

Gambar 4. Pengaruh varietas jagung terhadap aroma yoghurt

Gambar 4 menunjukkan bahwa varietas jagung tidak berpengaruh signifikan terhadap aroma yoghurt jagung. Aroma yoghurt jagung baik yang diuji secara skoring maupun hedonik menunjukkan tidak berbeda nyata antara varietas Pulut Putih, Pulut Ungu dan Provit A. Hasil uji sensoris secara skoring berada pada nilai 3,0-3,5 yang menunjukkan bahwa aroma yoghurt jagung dari seluruh varietas berada pada kriteria "agak beraroma jagung" sampai " tidak beraroma jagung". Penggunaan varietas Provit A menghasilkan yoghurt dengan aroma yang lebih kuat yaitu berada pada kriteria "agak beraroma jagung", sedangkan penggunaan varietas Pulut baik putih maupun ungu menghasilkan yoghurt dengan aroma jagung yang lebih lemah yaitu pada kriteria "tidak beraroma jagung". Adapun hasil uji sensoris secara hedonik, aroma yoghurt jagung dari seluruh varietas berada pada nilai 2,9-3,4 yang menunjukkan bahwa yoghurt 
Versi Online:

http://Www.profood.unram.ac.id/index.php/profood e-ISSN: $2443-3446$

jagung dari seluruh varietas berada pada kriteria "agak suka".

Aroma jagung khas pada jagung dihasilkan dari senyawa-senyawa volatil yang utama, yaitu dimetilsulfida, 1-hidroksi2propanon, 2-hidroksi-3-butanon, dan 2,3butanadiol (Zhou et al, 1999). Akan tetapi, berbeda dengan jagung segar, aroma khas jagung pada jagung pipil sedah mengalami penurunan yang signifikan. Hal ini berpotensi disebabkan karena aroma tersusun dari senyawasenyawa volatil maka diduga aroma bahan dasar sebagian besar hilang selama proses pengeringan jagung. Oleh karena itu, aroma jagung pada produk yoghurt yang dihasilkan cenderung lemah. Selain itu, pembentukan aroma khas yoghurt selama proses fermentasi akibat pembentukan komponen asam laktat, sisasisa aldehida, diasetil, asam asetat dan komponen volatil lainnya (Tamime dan Robinson, 2007) juga menutupi aroma khas jagung sebagai bahan dasar.

\section{Kenampakan}

Standar mutu yoghurt berdasarkan Standar Nasional Indonesia (SNI) 2981:2009 mensyaratkan kenampakan yoghurt adalah cairan kental sampai padat (Badan Standarisasi Nasional, 2009). Yoghurt mempunyai tekstur yang agak kental sampai semi padat dengan kekentalan yang homogen akibat dari penggumpalan protein karena asam organik yang dihasilkan oleh kultur starter (Surono, 2004). Selain faktor penggumpalan protein, kandungan bahan baku yang digunakan juga berpotensi mempengaruhi kenampakan yoghurt, salah satunya adalah perbedaan rasio antara amilosa dan amilopektin pada varietas jagung sebagai bahan baku pembuatan yoghurt. Hubungan antara varietas jagung dengan aroma yoghurt jagung baik secara skoring maupun hedonik dapat dilihat pada Gambar 5 .
Pro Food (Jurnal Ilmu dan Teknologi Pangan) Vol 7 No. 1 Mei 2021

ISSN: 2443-1095

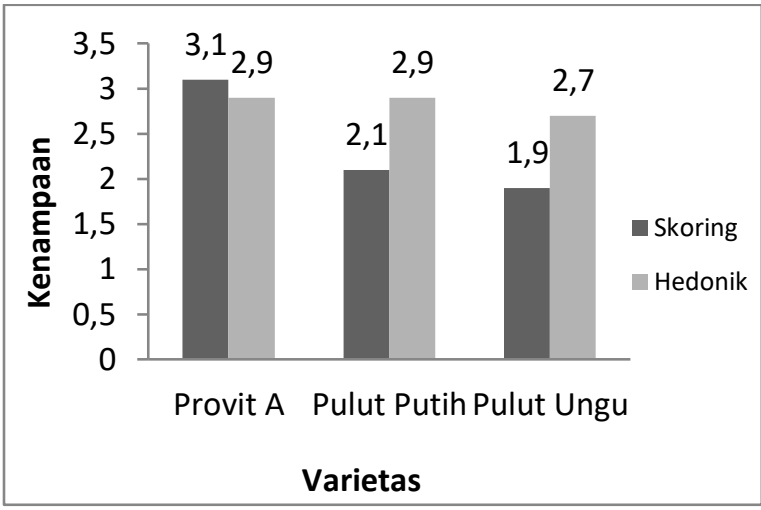

Gambar 5. Pengaruh varietas jagung terhadap kenampakan yoghurt

Gambar 5 menunjukkan bahwa kenampakan yoghurt jagung yang diuji secara skoring menunjukkan adanya berbeda nyata antara varietas Pulut Putih, Pulut Ungu dan Provit A. Hasil uji sensoris secara skoring berada pada nilai 1,9-3,1 yang menunjukkan bahwa kenampakan yoghurt jagung dari seluruh varietas berada pada kriteria "kental" sampai dengan "agak kental". Penggunaan varietas Provit A menghasilkan yoghurt dengan kenampakan berada pada kriteria "agak kental" dan berbeda nyata dengan dua varietas jagung lainnya yaitu Pulut Putih dan Pulut Ungu yang menghasilkan yoghurt dengan kenampakan yang berada pada kriteria "kental". Perbedaaan rasio antara amilosa dan amilopektin pada varietas Pulut Putih dan Pulut Ungu dengan varietas Provit A merupakan faktor utama yang mendorong perbedaan kenampakan yoghurt yang dihasilkan. Varietas Pulut Putih dan Pulut Ungu tergolong jagung ketan yang memiliki kandungan amilopektin yang sangat tinggi yaitu berkisar antara $90-99 \%$ dengan kandungan amilosa yang rendah yaitu berkisar antara 5,15-6,94\% (Suarni dkk, 2019). Perbedaan rasio amilosa dan amilopektin inilah yang berkontribusi terhadap perbedaan karakter fisikokimia termasuk kenampakan yoghurt yang dihasilkan. Adapun hasil uji sensoris secara hedonik tidak menunjukkan adanya beda nyata antara kenampakan dari seluruh varietas yang digunakan. Kenampakan yoghurt jagung dari seluruh varietas berada pada nilai 2,9-3,4 yang 
Versi Online:

http://www.profood.unram.ac.id/index.php/profood e-ISSN: 2443-3446

menunjukkan bahwa yoghurt jagung dari seluruh varietas berada pada kriteria "agak suka".

\section{KESIMPULAN}

Varietas jagung yang digunakan dalam pembuatan yoghurt memberikan pengaruh yang nyata terhadap nilai $\mathrm{pH}$, total Bakteri Asam Laktat dan kenampakan secara skoring. Penggunaan varietas Jagung Pulut Ungu merupakan perlakuan terbaik berdasarkan nilai pH 3,88, total Bakteri Asam Laktat tertinggi yaitu 8,7 log $\mathrm{CFU} / \mathrm{ml}$, kenampakan yang memenuhi persyaratan SNI yaitu kental serta rasa dan aroma yang dapat diterima oleh panelis.

\section{Daftar pustaka}

Aurum, F. S., 2009. Kajian Karakteristik Fisiko Kimia dan Sensori Yoghurt dengan Penambahan Ekstrak Ubi Jalar (Ipomoea batatas L.). Skripsi. Universitas Sebelas Maret. Surakarta.

Badan Pusat Statistik Provinsi NTB, 2019. Nusa Tenggara Barat dalam Angka 2019. Badan Pusat Statistik. Nusa Tenggara Barat

Badan Standarisasi Nasional, 2009. SNI Yoghurt (SNI 01-2981-2009). Dewan Standar Indonesia. Jakarta.

Balai Pengkajian Teknologi Pertanian Provinsi NTB, 2021. Pengenalan Varietas Unggul Baru Produk Balitbangtan. Balai Pengkajian Teknologi Pertanian. Nusa Tenggara Barat

Dinas Komunikasi Informatika dan Statistik NTB, 2019. Statistik Sektoral Bidang Ekonomi Tahun 2019. Pemerintah Nusa Tenggara Barat Dinas Komunikasi Informatika dan Statistik. Nusa Tenggara Barat

Djunaedi, D., 2007. Pengaruh Probiotik pada Respon Imun.Jurnal Kedokteran Brawijaya. 23 (1): 22-27

Ingraham, J.L., O. Maaloe, and F.C. Neidhardt, 1983. Growth of The Bacterial cell. Sunderland MA: Sinauer Associates; $\mathrm{p}$. 130.
Pro Food (Jurnal IImu dan Teknologi Pangan) Vol 7 No. 1 Mei 2021 ISSN: 2443-1095

Hartini, K., 2020. Pengaruh Konsentrasi Karagenan dan Lama Fermentasi Terhadap Viabilitas Lactobacillus acidophilus sebagai Probiotik dan Sifat Sensoris Cocoghurt. Skripsi. Fakultas Teknologi Pangan dan Agroindustri. Universitas Mataram. Mataram

Jannah, A. M., A. M. Legowo, Y. B. Pramono, A. N. AlBaarri, dan S. B. M. Abduh. 2014. Total Bakteri Asam Laktat,Keasaman, Cita Rasa, dan Kesukaan Yoghurt Drinkdengan Penambahan Ekstrak Buah Belimbing. Jurnal Aplikasi Teknologi Pangan. 3(2):7-11.

Kementerian Pertanian Republik Indonesia. 2018. NTB Provinsi Ketiga Ekspor Jagung ke Filipina. Diakses dari https://www.pertanian.go.id/home/?sho $\mathrm{w}=$ news\&act $=$ view\&id $=2587$

Kusumaningsih, T., 2014. Peran Bakteri Probiotik terhadap Innate Immune Cell. Oral Biology Journal. 6 (2): 45-50

Laeli, H., 2016. Kajian Sifat Kimia dan Sensoris Yogurt Jagung Manis (Zea mays Saccharata) dengan Menggunakan Beberapa Jenis Inokulum. Skripsi. Fakultas Teknologi Pangan dan Agroindustri.Universitas Mataram. Mataram

Lee, W.J. dan J.A. Lucey, 2010. Formation and physical properties of yogurt. Asian Aust. J. Anim. Sci. 23(9): 1127-1136

Meilawanti, 2020. Pengaruh Konsentrasi Karagenan dan Lama Fermentasi Terhadap Viabilitas Lactobacillus casei sebagai Probiotik dan Sifat Sensoris Cocoghurt. Skripsi. Fakultas Teknologi Pangan dan Agroindustri. Universitas Mataram. Mataram

Muchtadi, D. 2006. Karbohidrat dalam Makanan Bayi. Food review Referensi Industri dan Teknologi Pangan Indonesia 1(3):44-45.

Nadra, M.C.M, 2007. Nitrogen metabolism in lactic acid bacteria from fruits: a review. Communicating Curent Research and 
Versi Online:

http://www.profood.unram.ac.id/index.php/profood e-ISSN: 2443-3446
Pro Food (Jurnal IImu dan Teknologi Pangan) Vol 7 No. 1 Mei 2021 ISSN: 2443-1095

Educational Topics and Trends in Applied Microbiology. 500-510.

Ningsih, L.S., 2018. Uji Sensoris dan Viabilitas Bakteri Asam Laktat pada Soyghurt yang Dikombinasikan dengan Buah Naga Merah (Hylocereuspolyrhizus) Selama Penyimpanan. Skripsi. Fakultas Teknologi Pangan dan Agroindustri. Universitas Mataram. Mataram

Nizori, A. S., V. Surhaini., Mursalin, Melisa, T. C, Suharni, dan E. Warsi, 2008.Pembuatan Soyghurt Sinbiotik Sebagai Makanan Fungsional dengan Penambahan Kultur Campuran Streptococcus thermophilus, Lactobacillus bulgaricus dan Lactobacillus acidophilus.Jurnal Teknologi Industri Pertanian. 18(1):28-

33.

Nurkayanti, H., 2019. Pengaruh Konsentrasi Lactobacillus acidophilus Terhadap Mutu Yoghurt Sari Kacang Komak (Lablab purpureus (L.) Sweet). Skripsi. Fakultas Teknologi Pangan dan Agroindustri. Universitas Mataram. Mataram

Suarni, M. Aqli dan H. Subagio, 2019. Potensi Pengembangan Jagung Pulut Mendukung Diversifikasi Pangan. Jurnal Litbang Pertanian. 38 (1) : 1-12

Surono, I. S., 2004. Probiotik Susu Fermentasi dan Kesehatan. Yayasan Pengusaha Makanan dan Minuman Seluruh Indonesia. Jakarta.

Tamime, A.Y. dan R.K. Robinson, 2007. Yoghurt - Science and Technology. Third Edition. CRC. Woodhead Publishing Limited. Cambridge. England.

Usmaningtia, R., 2019. Pengaruh Konsentrasi Lactobacillus casei Terhadap Mutu Yoghurt Sari Kacang Komak (Lablab Purpureus (L) Sweet)". Skripsi. Fakultas Teknologi Pangan dan Agroindustri. Universitas Mataram. Mataram 